\title{
Energy and Environment
}

SANDIA NATIONAL LABORATORIES • Albuquerque, NM • Livermore, CA • Operated by Sandia Corporation for the U.S. Dept. of Energy

\begin{tabular}{|l|}
\hline Inside this issue \\
Swoosh! new system \\
vacuums up drill cuttings \\
Safer air drilling for \\
environmental remediation \\
sites ................................
\end{tabular}

Energy and environment news in brief ................2

Reducing operating and maintenance costs at solar power plants For their future to be bright, economics must be favorable.

Direct probability mapping aids cleanup decisions

Don't map the contaminant - map the probability that it's a problem. ... 6

Nonintrusive landfill characterization saves time, gives thorough picture

Variety of approaches provides information vital for remediation.

Vacuum and filter system removes particles as small as 0.3 micrometer from air-drilling residue. Here, Jim Westmoreland adjusts controls of the system, which also traps volatile organic compounds.

\section{Swoosh! new system vacuums up drill cuttings}

Safer air drilling for environmental remediation sites

Desearchers in environmental remediation are investigating air drilling and Rother underground drilling methods that eliminate drilling fluids. The reason: fluids can provide a pathway for spreading contamination, possibly into groundwater aquifers. Air drilling uses compressed air with an air-driven

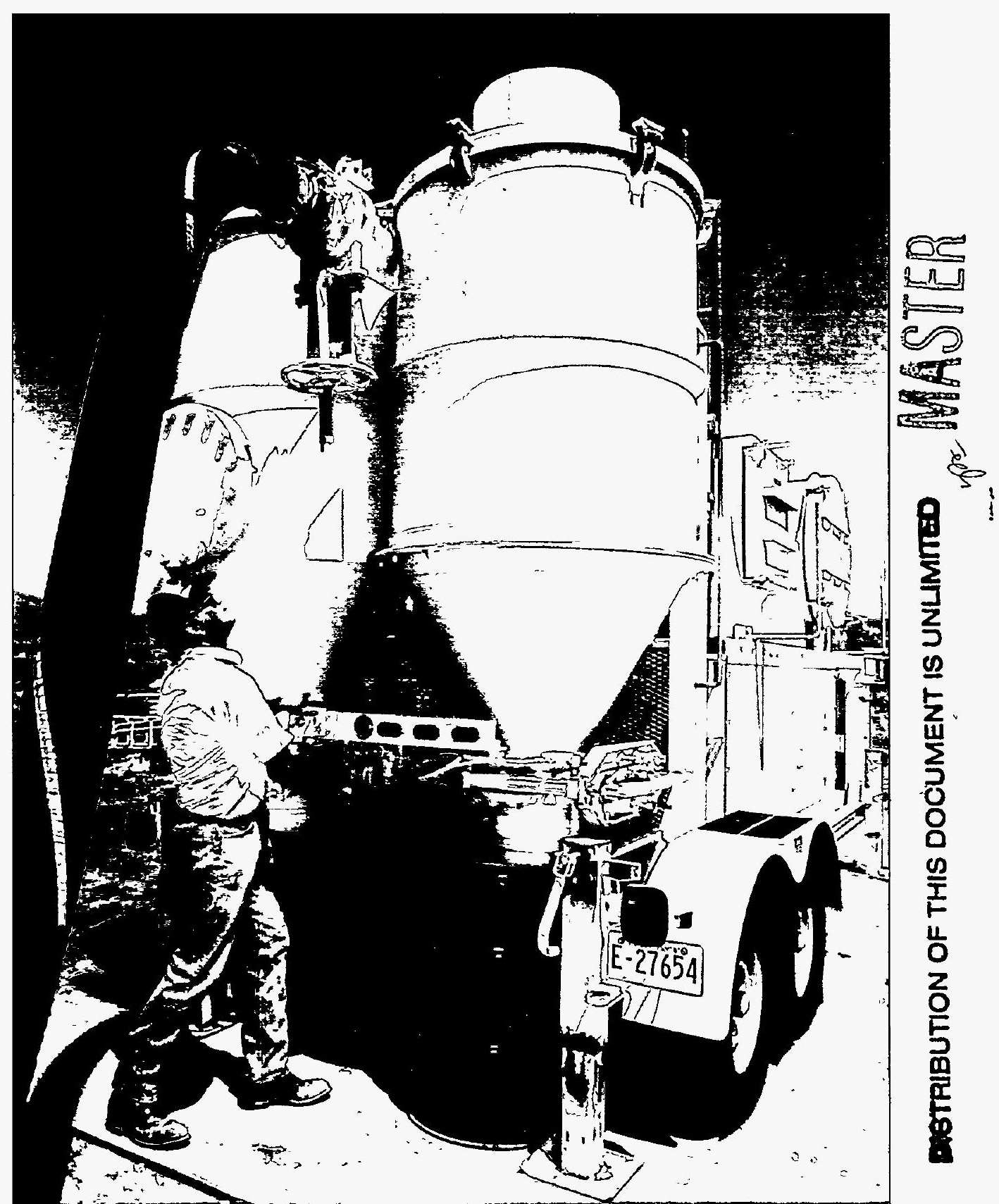




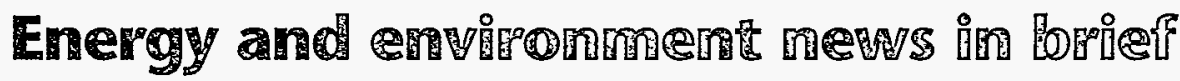

Photovoltaic cell, SEAMIST win R\&D 100 awards

Two new products in energy and environment are among the seven for which Sandia won R\&D 100 awards this year. The competition, sponsored by R\&D magazine, recognizes the 100 most technologically significant new products of the year. Since 1976, Sandia has won 34 awards.

A high-performance silicon photovoltaic cell is more efficient than conventional cells and is amenable to high-volume manufacture by standard integrated-circuit processing technology. Sandia shared the award with the Electric Power Research Institute, DOE, Amonix, and SunPower Corporation.

James Gee, Org. 6219, (505) 844-7812, fax 844-6541

SEAMIST (Science and Engineering Associates Membrane Instrumentation and Sampling Technique) uses an impermeable tubular membrane to deploy sensors or samplers in boreholes for studying subsurface environments or monitoring them for hazardous materials. Sandia shared the award with two New Mexico companies: Science and Engineering Associates, of Albuquerque, and Eastman Cherrington Environmental, of Santa Fe. SEAMIST was featured in Energy and Environment, October 1993.

Cecelia Williams, Org. 6621, (505) 844-5722, fax 844-0543

EnviroTRADE expands in former Soviet Union

With Earth Data Systems, dispersed researchers work together

Utility-scale dish-Stirling projects under way
One of the Sandia developers of an electronic information system that matches environmental problems with technological solutions recently oversaw installation of three new system workstations in Russia. The first EnviroTRADE (Environmental Technologies for Remedial Actions Data Exchange) workstation in the former Soviet Union was installed last year. Sun Microsystems supplied the latest three installed workstations along with two more workstations for future Russian locations. In return, Russia is providing DOE with environmental data that will help predict movement of contaminants in U.S. water, soil, and air.

Mark W. Harrington, Org. 6907, (505) 844-4221, fax 844-8734, or Charlene Harlan, Org. 6907, (505) 844-8164, fax 844-8734

Sandia is participating in Earth Data Systems, a high-speed computer network that links U.S. sites working on environmental and ecosystem projects. EarthDS is a multimedia application of the National Information Infrastructure Testbed that allows geographically dispersed users to work with 20 years of centrally located environmental data. Sandia-provided functions let researchers work with various data bases, carrying out tasks such as overlaying and analyzing satellite and aerial images of the earth's surface taken at different times, locations, and angles.

Chris Forsythe, Org. 12323, (505) 844-5720, fax 844-9037

Two multiyear government-industry projects could lead to use of dish-Stirling electrical power systems by utilities. In cost-shared partnerships, Sandia, Science Applications International, and Cummins Power Generation will design and build prototype dish-Stirling systems that produce 25 kilowatts of electricity each. If the prototypes are successful, the next phase could be deployment of arrays of dish-Stirling systems producing 2 megawatts.

Tom Mancini, Org. 6216, (505) 844-8643, fax 844-7786, or Don Gallup, Org. 6216, (505) 845-8793, fax 844-7786 


\section{DISCLAIMER}

Portions of this document may be illegible in electronic image products. Images are produced from the best available original document. 
downhole motor and drill bit. To avoid spreading contaminated material aboveground, such systems require containment of the stream of cuttings as it reaches the surface. The return air must be filtered to remove small particles. Most current methods use compressed air to move the drill cuttings back to the surface and through the containment and air-filtration process.

A Sandia study found that improvements could be made in containing the cuttings, filtering hazardous materials such as radionuclides and volatile organic compounds, and incorporating safety features such as alarms, instrumentation, and pressure safety equipment. In collaboration with a manufacturer of asbestos abatement equipment, Sandia has developed and tested an operational version of an improved containment system. A key improvement was to bring the cuttings to the surface with air at less than atmospheric pressure - like a vacuum cleaner - rather than compressed air, according to Jim Westmoreland of Sandia's Environmental Drilling Projects Department. As in conventional air drilling, air provided by a compressor flows into the system to drive the drill; for the return, low-pressure air, created by a large pump, pulls material through the containment side of the system. A diverter box, fitted with pressure relief valves and other safety features to prevent overpressurization, provides a transition for the two air flows. "Maintaining a lowpressure atmosphere in the cuttings return line is a better method of containment," says Westmoreland. "If a hose or pipe joint leaks, contaminated air doesn't escape to the external environment. Instead, materials will be drawn inward."

The Sandia system, developed and constructed in collaboration with Guzzler Manufacturing, of Birmingham, Alabama, was first tested at Sandia's Directional Boring Test Range and is now being tested at DOE's Hanford Plant near Richland, Washington. The 25-foot-long ( 7.6 meters), 16,000-pound (7,300 kilograms) unit has four filtering stages to capture even very fine materials. As a Roots pump pulls the air stream through the system, a cyclone unit first sets the solid particles and air stream into a spinning path, which causes heavier materials to fall out of suspension and be captured. This removes more than 95 percent of the materials being vacuumed, says Westmoreland. Next, the stream passes through a stainless steel baghouse filled with 36 cylindrical bags that filter particles down to 1 micrometer in size. Finally, the stream passes through high-efficiency particulate air filters, which screen particles down to 0.3 micrometers, and charcoal filters, which remove volatile organic compounds. Isolation valves allow changing the route of the vacuum flow to replace filters without disrupting operations or exposing workers or the environment to contaminants.

Development of the cuttings containment system was sponsored by DOE's Office of Technology Development, Sandia's Mixed-Waste Integrated Landfill Demonstration, and Westinghouse-Savannah River Non-arid Site Integrated Demonstration. In addition to the tests at Hanford, other DOE facilities are considering evaluating the system. It could prove useful at many sites, predicts Westmoreland: "As air drilling is used more frequently at environmental sites, this containment system could contribute significantly to safer operations and better hazardous material disposal." 团

For more information, call

Jim Westmoreland, Org. 6111, (505) 844-0482, fax 844-3952.
Like a giant vacuum cleaner, the cuttings containment system pulls air-drilling residues from underground and catches them in a series of filters.

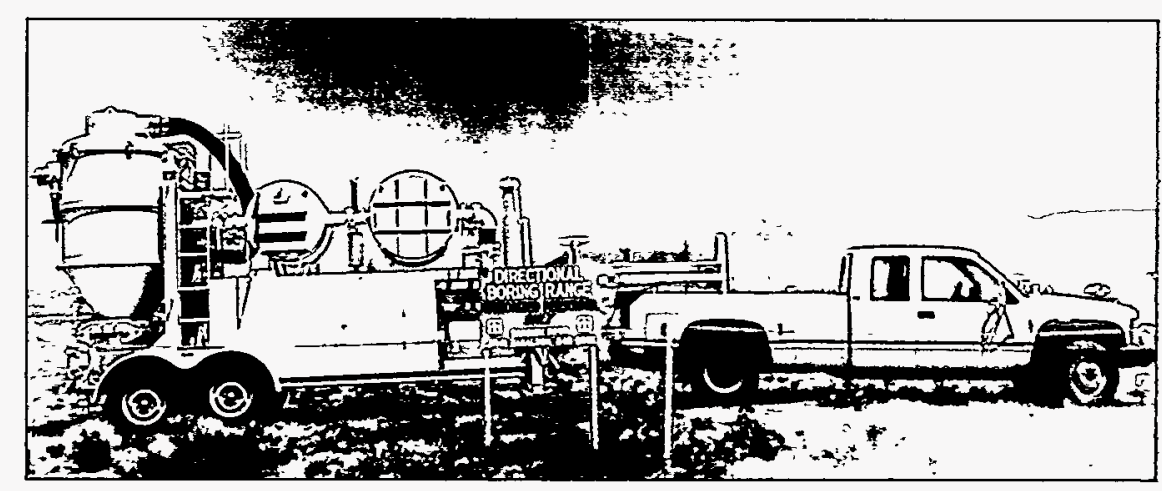

Trailer-mounted containment system is moved into position for testing. 


\title{
Reducing operating and maintenance costs at solar power plants
}

\author{
For their future to be bright, economics must be favorable
}

\begin{abstract}
A lthough commercial-scale solar thermal power plants are in their infancy, experience already shows that operating and maintenance costs are critical to economic viability. Sandia is helping reduce the O\&M costs of solar plants, partly so operators can gain near-term cost reduction, but ultimately to help ensure large-scale deployment of solar power in the next century.

A real-world laboratory for a variety of cost reduction efforts is provided by several plants among the nine built in Southern California's Mojave Desert between 1985 and 1991. These plants produce a total of 354 megawatts of electricity, more than 90 percent of the world's grid-connected solar power. Constructed by LUZ Corp., the plants incorporate many design features developed at Sandia in the late 1970s and early 1980s. Thousands of parabolictrough collectors concentrate solar energy onto vacuum-jacketed receiver tubes, which heat a synthetic oil to more than $370^{\circ} \mathrm{C}$. The hot oil passes through heat exchangers to make steam that drives a turbine-generator.
\end{abstract}

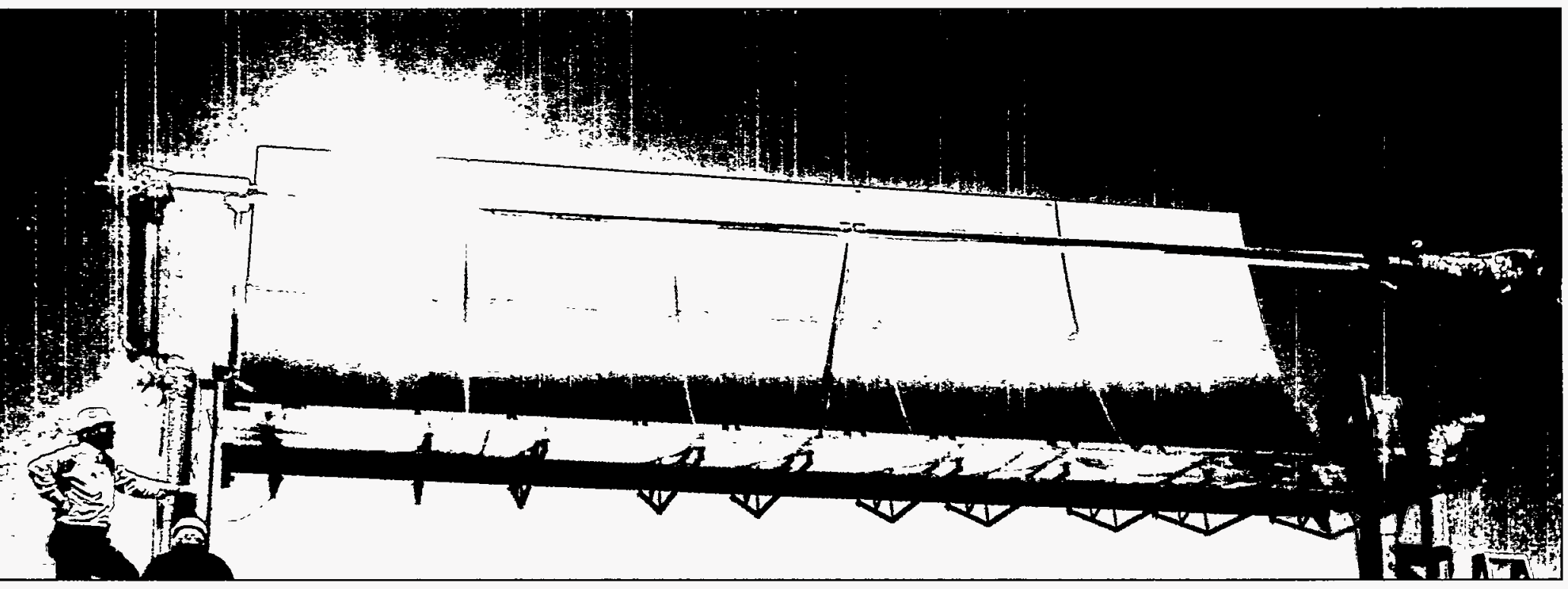

Above: Solar collector undergoes testing on a rotating platform at Sandia. Because the collector can be constantly pointed at the sun, test conditions remain stable.

Opposite: Solar power plants such as this one in California will become more economically feasible as operating and maintenance costs are reduced through technical improvements.
Sandia and KJC Operating Co., which operates several of the Mojave Desert plants, are cooperating in a three-year project, funded jointly by $\mathrm{KJC}$ and DOE's Office of Energy Efficiency and Renewable Energy. Reducing O\&M costs - which make up more than 25 percent of the cost of solar-generated electricity - would improve the economics of both current and future plants. Several of the O\&M cost reduction techniques being investigated at the KJC plants apply also to other types of plants, such as the Solar Two central receiver due to come on-line in California before 1996. The overlap is because central receiver plants, also called power towers, have many of the same subsystems as KJC's plants. Described in this article are three efforts among a number being undertaken during the Sandia-KJC cost-reduction project.

The project team's first task was to categorize O\&M costs of KJC's 40-plus plant-years of operation. The study revealed that a significant amount was spent on replacing damaged receiver tubes, which cost about $\$ 1,000$ each. KJC asked Sandia to test receiver tubes with and without vacuum. "When the tests were performed at the National Solar Thermal Test Facility at Sandia," says 
Greg Kolb of the Solar Thermal Technology Department, "the results showed that tubes with broken glass sleeves had two to five times higher heat loss than tubes with good vacuum, depending on wind speed. KJC is using these results to evaluate the cost of the tubes vs. the performance loss of not replacing tubes that lose their vacuum."

Another need of a solar plant is clean mirrors. Producing 350 megawatts takes about a square mile of mirrors, and cleaning that large surface area drives up costs. To keep mirror-cleaning costs as low as possible, operating companies need to measure mirror reflectance frequently to define optimum cleaning schedules and techniques. "Previous instruments for making these measurements were adequate for the small solar research facility at Sandia," says Kolb," but they were too cumbersome to be practical for measuring the reflectance of commercial-scale solar fields." During the past year, Sandia's Rod Mahoney has worked with TMA Technologies to develop an easier-to-use reflectometer. This new device, called the Microscan Scatterometer, is portable, weighs less than a kilogram, can record data, and is compatible with personal computers. Tests at solar generating plants indicate that the Microscan will reduce the time needed to perform and analyze reflectance measurements to one-fifth of that previously required.

When multiple solar plants are located together, as are the five plants operated by KJC at Kramer Junction, California, the result is a solar power park that can use a single maintenance crew; the maintenance cost for each plant is thus reduced. Power parks are expected to become more common as commercial solar plants are constructed during the 21st century. To fully benefit from shared services, maintenance planners must have rapid access to maintenance data at each plant. They must also have a method of quickly ordering any required work and replacement parts. Toward this end, an integrated data-collection network and maintenance-planning software have been installed at Kramer Junction, giving each plant a computer workstation connected to the park's maintenance planning organization. Sandia reliability specialists are ensuring that the system will properly track information such as component reliability. This system is expected to improve maintenance efficiency by more than 20 percent. 困

For more information, call

Greg Kolb; Org. 6216, (505) 844-1887, fax 844-7786.
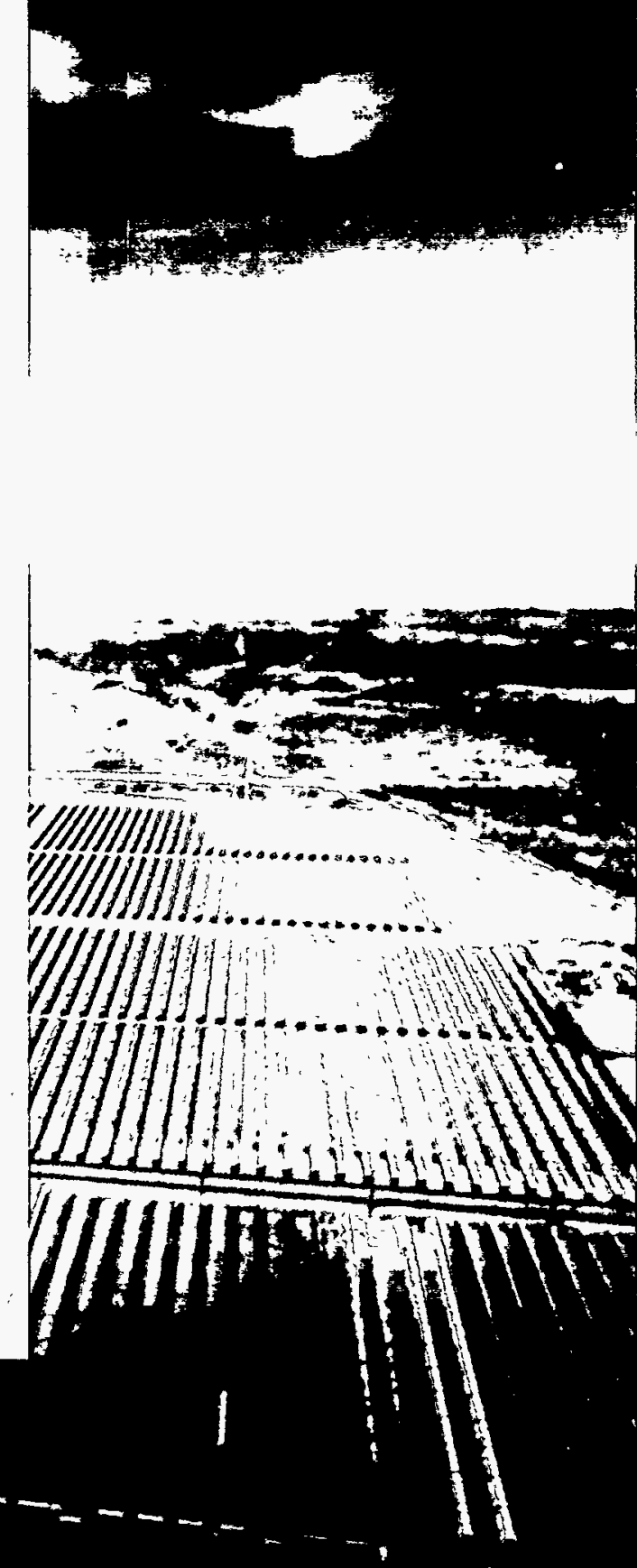

,

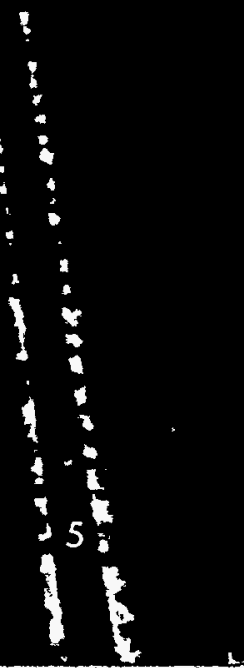




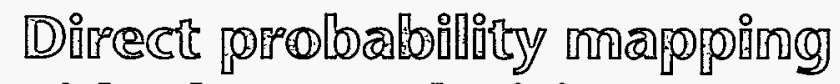 di̊ds cleanup decisions \\ Don't map the contaminant - map the probability that it's a problem}
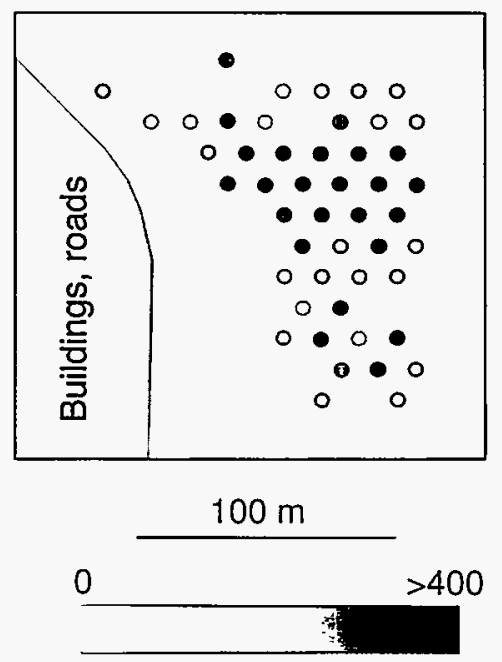

Uranium level, picocuries/gram
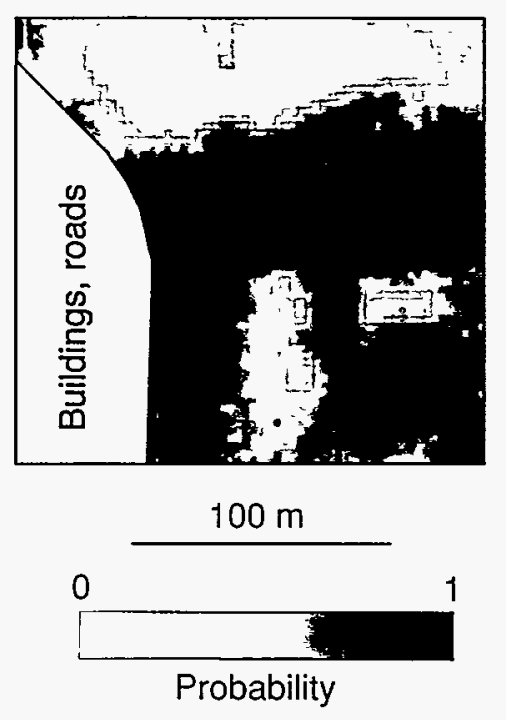

Upper: Dots show uranium levels found by soil sampling. (Dots are much larger than actual sample areas.)

Lower: Gray-scale coding shows probability that a given area of ground contains uranium exceeding 200 picocuries per gram. Probabilities are derived from discrete samples; note 0.5 probability (medium gray) in unsampled regions.
$\mathbb{W}$ here do we send the bulldozer? A bulldozer isn't always the tool of choice, but the basic question in environmental cleanup is still the same: On the basis of discrete individual samples, what areas should a site operator treat? To help operators decide which regions to treat - or whether to take further samples - Sandia researchers are applying new geostatistical methods in a novel way. Their approach, called direct probability mapping, offers decision criteria to site operators and lets them evaluate the risk associated with a given decision. The technique applies to a wide variety of environmental restoration projects.

Direct probability mapping is a way to deal with the fragmentary nature of site sampling. When a site is characterized, physical sampling provides the data to distinguish uncontaminated areas from those that exceed a particular threshold level, as specified by a regulatory agency. But samples are collected at individual locations, points out Chris Rautman of Sandia's Geohydrology Department, and there is always uncertainty about the status of the regions between sample sites. "Despite that uncertainty," says Rautman, "the site operator has to make decisions: "Where do I send the bulldozer? If I clean up this region but not that one, what are the chances that I'm missing something? Would more samples help reduce the area I need to clean up, or reduce the risk that I'm making a mistake?' "

Various methods are used to convert isolated sample data into maps of the distribution of contamination, says Rautman. "Although these modeling techniques range from purely subjective to quite mathematical, their common weakness is that they do not address the uncertainty issues. We address the uncertainty by calculating and directly mapping the probability that any location exceeds a particular concentration of contaminant, given a particular set of sample data." Thus, instead of a site map that attempts to show actual contamination levels, the Sandia team's method displays the probability that, at each location, the contamination is greater than a specific threshold value.

Besides using the sampled data values themselves, the geostatistical methodology also extracts additional information from spatial continuity patterns (the degree to which contamination at one point is correlated with another point) that may be inferred from the samples. All this information is then used to calculate probability levels. Though a probability may say little about the actual contamination level, it can be more useful than an estimate of the contamination level. It aids decisions about treatment, because it directly addresses requirements to treat all areas that are above a given threshold. Put another way, probability levels reflect the degree of risk that a parcel left untreated is actually contaminated.

Rautman and coworkers are applying direct probability mapping in a demonstration project sponsored by the DOE Office of Technology Development at the former Fernald Feed Material Processing Center near Cincinnati. In that project, standard soil samples have been collected and analyzed for uranium. On the basis of the samples, the Sandia team calculates and displays the probability that contamination by particulate uranium exceeds any of several threshold values. The probabilities are for 3-by-3-meter parcels, which correspond approximately to the width of a bulldozer blade. (If the decision is to remediate a certain region, that area may represent the minimum size parcel that can be treated individually.) The probability that each individual parcel 
exceeds the threshold is gray-scale coded between zero and one.

In evaluating possible site characterization and remediation plans, operators can use probability mapping output in decision models to help select the riskadjusted, least-cost alternative. Besides providing data for deciding whether to remediate a specific area, the information can also reveal where further sampling would be worthwhile. Where the probability of contamination above a threshold level is either very high or very low, little would be gained by additional sampling. The most cost-effective use of characterization resources is sampling to reduce the area of greatest uncertainty. 团

For more information, call

Chris Rautman, Org. 6115, (505) 848-0707, fax 848-0605, or Paul Kaplan, Org. 6312, (505) 848-0684, fax 848-0739.
Energy and Environment available on-line

Electronic access to this newsletter is available through New Mexico

Technet and Predicasts' Newsletter Database through the DIALOG, DataStar, and Dow Jones

News/Retrieval host systems. For information on using NM Technet, call (505) 345-6555; for Predicasts, call (800) 321-6388.

\section{Nonintrusive landfill characterization saves time, gives thorough picture Variety of approaches provides information vital for remediation}

J ust as successful manufacturing often depends on a wide variety of technologies, so does successful environmental characterization. At least, that's the view of Sandia environmental scientists Rarilee Conway and John Cochran. Sponsored by DOE's Environmental Management Office, Sandia's Environmental Restoration Project demonstrated the advantages of such an approach while identifying and characterizing inactive disposal sites at Sandia's New Mexico facility, where high explosives have been used since the late 1940s. By carefully screening and adopting emerging characterization technologies from the private sector, project leaders Conway and Cochran developed an approach that proved effective, quick, and thorough.

"We took a close look at time and cost when selecting technologies," says Conway. In the area being surveyed, characterization had to be performed quickly because operations in the area limited access to one or two days a week. Characterization also had to be nonintrusive. "Because of the possibility of inadvertently drilling into hazardous waste, intrusive characterization would have required protective clothing, safety equipment, and administrative hurdles that would have increased costs and delayed schedules," says Conway.

Several nonintrusive characterization technologies were selected and used: magnetic and electromagnetic geophysical surveys, passive soil vapor surveys, and even aerial photography. "To the best of my knowledge, this is the first remediation project to use this specific combination of characterization approaches,". says Conway.

Geo:Centers Inc. used its Surface Towed Ordnance Locator System to look for buried magnetic objects. STOLS uses a system of seven magnetometers towed across an area; the location at any time is pinpointed with submeter accuracy-by the satellite-based Global Positioning System. The magnetometers measure magnetic field changes caused by buried ferrous (iron-containing) objects, STOLS provides ultrahigh-resolution data $-10,000$ to 100,000 points per acrẹ. In the first commercial application of STOLS, Geo-Centers surveyed 20 acres in a day; identifying 311 magnetic anomalies corresponding to buried waste, underground utilities, and other buried materials.

Lamb Associates conducted conventional and high-resolution electromagnetic-surveys. Because electromagnetic methods can detect nonferrous objects, the electromagnetic surveys added important information to the magnetic survey." We appreciated the opportunity to compare high-resolution electromagnetic imaging with high-resolution magnetic imaging," says Lamb's David

This hand-towed electromagnetic system, a Geonics product, can be converted to a humancarried configuration in terrain too rough for wheels. 


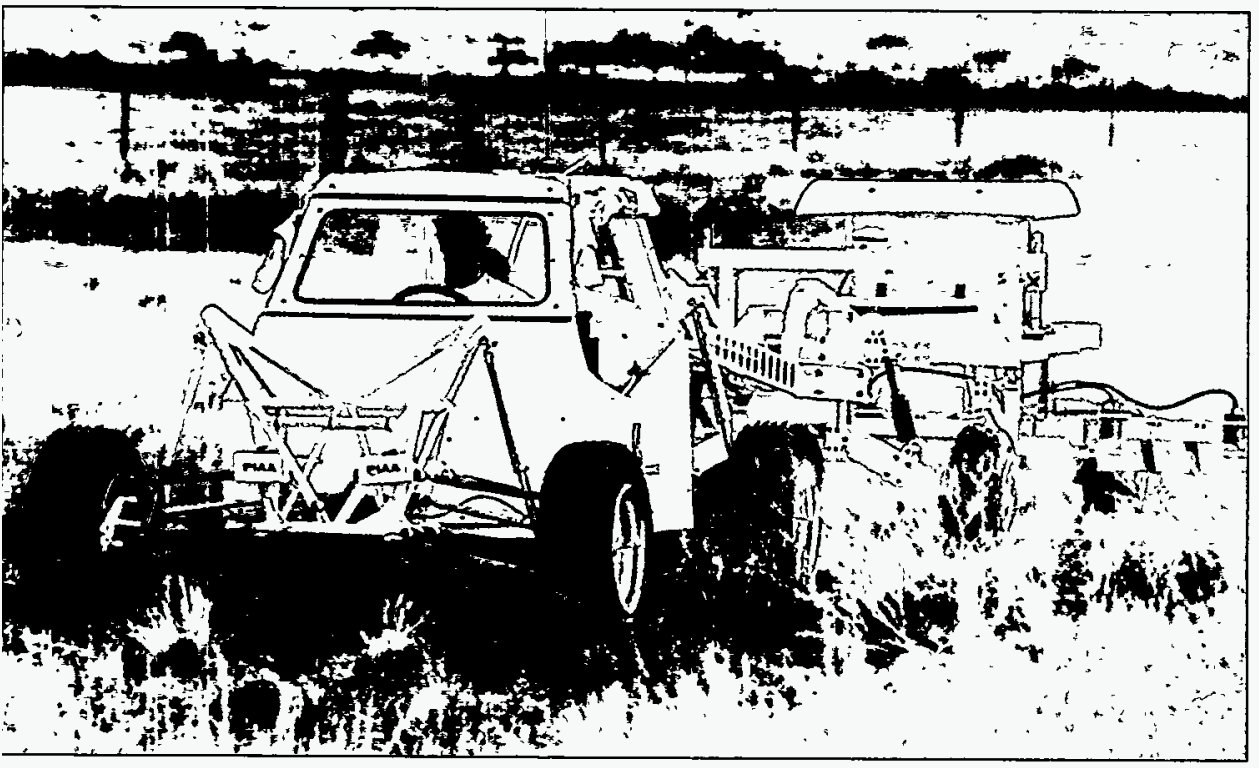

Hyndman. "It's one of the best comparisons that's been carried out anywhere."

Geo-Centers also benefited. "Sandia gave us a knowledgeable and relevant technical critique of our system," reports Geo-Centers' Jack Foley. "Partially because of this work, Geo-Centers is considering building a multiple sensor system that will collect both magnetic and electromagnetic data simultaneously."

Sandia scientists also conducted passive soil vapor surveys using equipment from Northeast Research Institute. Sandia researchers were able to install the sampling equipment quickly and leave it in the ground for several days. Because this approach collects samples over an extended period, it smooths

Surface Towed Ordnance Locator System scans for buried magnetic objects. STOLS is a product of Geo-Centers, Inc. temporal variations that can plague other vapor-sampling methods.

In an additional nonintrusive investigation, Ebert and Associates, of New Mexico, analyzed historical aerial photographs. "By interpreting 27 years of aerial photographs dating back to the 1950s, we were able to map 1,261 features related to waste disposal," says vice president Jim Ebert. "I am not aware of anybody else who has used photo interpretation for environmental characterization to such a detailed extent." The photos revealed a chemical disposal pit not found with the other characterization techniques.

Together, say Conway and Cochran, these investigations provided a detailed assessment of disposal sites, demonstrating the value of applying multiple nonintrusive characterization techniques. 团

For more information, call

Rarilee Conway, Org. 7582, (505) 848-0383, fax 848-0417

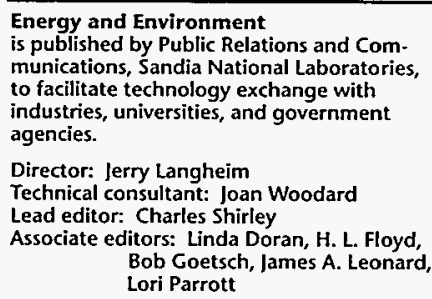



This work performed at Sandia National Laboratories is supported by the US Department of Energy under contract DE-ACO4-94AL85000

作

Thus report was prepared as an account of work sponSored by an agency of the United States Covernment. thereot, nor any of therr employees, nor any of therr coniractors, subcontractors, or therr employees, makes any warranty, express or implied, or assumes any legal flablity or responsibilty for the accuracy, completeness. or usefulness of any information, apparatus, product, or process disslosed, or represents that is use would not specic commercial product process or service by trade name, trademark, manufactures, or otheruse does not necessanly constitute or imply its endorsement, recommendation, or favoring by the United

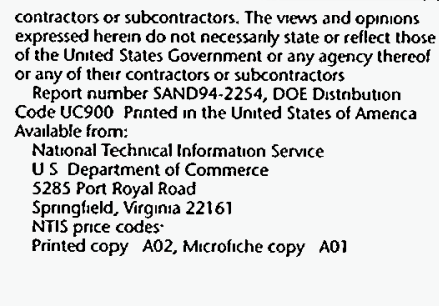

contractors or subcontractors. The vews and opinions encer contractors or subcontraciors Coport number SAND94-2254, DOE Distribution Natonal Technical information Service Springtheld, Virginia 2216 iinted copy $A 02$, Microfiche copy $A 0$

\section{SANDIA TECHNOLOGY BULLETIN}

Laboratory Communications Dept. 12610 Sandia National Laboratories

P.O. Box 5800

Albuquerque, NM 87185-0129

address correction requested

\section{DISCLAIMER}

This report was prepared as an account of work sponsored by an agency of the United States Government. Neither the United States Government nor any agency thereof, nor any of their employees, makes any warranty, express or implied, or assumes any legal liability or responsibility for the accuracy, completeness, or usefulness of any information, apparatus, product, or process disclosed, or represents that its use would not infringe privately owned rights. Reference herein to any specific commercial product, process, or service by trade name, trademark, manufacturer, or otherwise does not necessarily constitute or imply its endorsement, recommendation, or favoring by the United States Government or any agency thereof. The views and opinions of authors expressed herein do not necessarily state or reflect those of the United States Government or any agency thereof. 